\title{
Landslide and debris flow susceptibility zonation using TRIGRS for the 2011 Seoul landslide event
}

\author{
D. W. Park, N. V. Nikhil, and S. R. Lee \\ Korea Advanced Institute of Science and Technology, Daejeon, Republic of Korea \\ Correspondence to: S. R. Lee (srlee@kaist.ac.kr) \\ Received: 23 April 2013 - Published in Nat. Hazards Earth Syst. Sci. Discuss.: 5 June 2013 \\ Revised: 10 October 2013 - Accepted: 15 October 2013 - Published: 14 November 2013
}

\begin{abstract}
This paper presents the results from the application of a regional, physically based stability model: Transient Rainfall Infiltration and Grid-based Regional Slope-stability analysis (TRIGRS) for a region on Woomyeon Mountain, Seoul, South Korea. This model couples an infinite-slope stability analysis with a one-dimensional analytical solution to predict the transient pore pressure response to the infiltration of rainfall. TRIGRS also adopts the geographic information system (GIS) framework for determining the whole behaviour of a slope. In this paper, we suggest an index for evaluating the results produced by the model. Particular attention is devoted to the prediction of routes of debris flow, using a runoff module.

In this context, the paper compares observed landslide and debris flow events with those predicted by the TRIGRS model. The TRIGRS model, originally developed to predict shallow landslides, has been extended in this study for application to debris flows. The results predicted by the TRIGRS model are presented as safety factor (FS) maps corresponding to transient rainfall events, and in terms of debris flow paths using methods proposed by several researchers in hydrology.

In order to quantify the effectiveness of the model, we proposed an index called $\mathrm{LR}_{\text {class }}$ (landslide ratio for each predicted FS class). The $\mathrm{LR}_{\text {class }}$ index is mainly applied in regions where the landslide scar area is not well defined (or is unknown), in order to avoid overestimation of the model results. The use of the TRIGRS routing module was proposed to predict the paths of debris flow, especially in areas where the rheological properties and erosion rates of the materials are difficult to obtain. Although an improvement in accuracy is needed, this module is very useful for preliminary spatio-temporal assessment over wide areas. In summary, the
\end{abstract}

TRIGRS model is a powerful tool of use to decision makers for susceptibility mapping, particularly when linked with various advanced applications using GIS spatial functions.

\section{Introduction}

Shallow landslides involving colluvium are generally the most common in South Korea and often mobilize into destructive debris flows. Shallow landslides are typically 1-3 m deep and often occur at boundaries between the colluvium and the underlying more solid parent rock (Salciarini et al., 2008). In most parts of South Korea, including Seoul, the thickness of the colluvium is generally less than $2 \mathrm{~m}$ because of the relatively shallow depth of the bedrock, and hence shallow landslides are frequent. Furthermore, the climate of South Korea is typical of the Indian Ocean monsoon, with pronounced seasonal precipitation (Kim et al., 2010). Thus, rainfall-triggered landslides are a recurring problem in South Korea. Due to the mountainous terrain with a shallow layer of colluvium, and associated weather conditions, landslides have proven a hazard across most of the country. The socioeconomic impact, moreover, has become much higher than before because of the current population levels in the hazardous zones.

During 26-27 July 2011, in particular, heavy rainfall ( $470 \mathrm{~mm}$ in two days) occurred in Seoul, an amount approximately equal to $20 \%$ of the total annual rainfall for that region. During this precipitation event, 147 catastrophic landslides occurred on Mt. Woomyeon. Most of the landslides were accompanied by debris flows, and these mixtures of debris flowed down roads into the surrounding communities. Sixteen people were killed and ten buildings 
damaged by these debris flows. During the storm, shallow landslides on steep mountainous terrain were mostly triggered by heavy rainfall that increased the pore pressure of soil in the near-subsurface, with an attendant decrease in its shear strength. Under these conditions, precipitationinduced landslides caused translational mass movements that occurred suddenly.

In order to understand when and where rainfall-induced landslides have occurred in mountainous regions, and how topographic, geotechnical and hydraulic parameters affect the initiation of landslides and might be used to predict them, models adopting both empirical and deterministic approaches have been used.

SMORPH (Shaw and Johnson, 1995), which stands for Slope MORPHology, is an empirical model adapted to include the contributing area with creeping process. One advantage of this model is that it only uses parameters derived from a digital elevation model (DEM) to calculate susceptibility, and does not require field mapping.

In contrast, physically based or deterministic models are more frequently used for specific catchments, because there are physical descriptions that can be used to inform mathematical equations about slope failure processes. Five such models are introduced below, and compared with Transient Rainfall Infiltration and Grid-based Regional Slope-stability analysis (TRIGRS), the model upon which this work is focused.

LISA (Hammond et al., 1992) stands for Level I Stability Analysis. It identifies the effects of the tree root strength and tree surcharge on slope stability as an important parameter of forested, hill-slope areas. LISA enables the user to compute the probability of slope failure using up to 1000 iterations of a Monte Carlo simulation, by varying input values involved in the infinite slope equation. The Monte Carlo simulation estimates the probability of failure rather than a single factor of safety value.

SHALSTAB (Dietrich et al., 1993, 1995; Montgomery and Dietrich, 1994; Montgomery et al., 1998) stands for Shallow Slope Stability Model. It is a coupled, steady-state runoff and infinite-slope stability model which can be used to map the relative potential for shallow sliding. The model has been improved by various fellow scientists. As a result, this model correctly predicts the observed tendency for soils to be thick in the un-channelled valleys and thin on ridges (Dietrich et al., 1995).

The dSLAM (Wu and Sidle 1995; Dhakal and Sidle, 2003), distributed Shallow Landslide Analysis Model, is a distributed, physically based model that combines an infinite slope model, a kinematic wave groundwater model, and a model simulating continuous changes in vegetation root strength, to analyse shallow, rapid landslides. This also includes results on the spatial distribution of safety factors in steep, forested terrain. This model is characterized by its focus on the stochastic influence of rainfall on pore water pressure.
SHETRAN (Ewen et al., 2000; Birkinshaw et al., 2010), which stands for System Hydrology European TRANsport, provides a hydrological and sediment transport framework for simulating landslides triggered by rain and snowmelt, along with sediment yield. In this model, the occurrence of shallow landslides is predicted as a function of the timeand space-varying soil saturation conditions, using an infinite slope model for safety analysis.

SINMAP (Pack et al., 1998, 2001), for Stability INdex MAPping, was developed in British Columbia with the support of the Canadian government. Compared to other models, the slope stability model SINMAP has merit in that it calculates the potential slide risk for shallow translational slides via the specific-slope water balance (Chinnayakanahalli, 2004).

TRIGRS (Baum et al., 2002, 2008) stands for Transient Rainfall Infiltration and Grid-based Regional Slopestability. It is written in FORTRAN code and based on Iverson's (2000) linearized solution of the Richards equation, and the extension of that solution. The TRIGRS model, used for either saturated or unsaturated soils, is able to improve the effectiveness of susceptibility analysis by accounting for the transient effects of varying rainfall on conditions affecting slope stability. It has been used successfully around the world for quantitatively evaluating rainfall-triggered landslides, and a number of those applications follow.

1. TRIGRS was used in a case study to account for the transient effects of rainfall on shallow landslide initiation, and verified with pilot catchments. Some examples include the Seattle area, Washington, USA (Godt et al., 2008); Mt. Tenliao, Taipei, Taiwan (Chen et al., 2005); and Mt. Gyemyeong, Yangju, South Korea (Kim et al., 2010).

2. TRIGRS was used to evaluate and compare other physically based models including SLIP (Montrasio, 2011), SHALSTAB (Sorbino, 2010), SINMAP and LISA (Morrisey et al., 2001). The latter mentioned that Iverson's model, which is the basis of TRIGRS, would be preferred among the three models described above, because only Iverson's transient response model can assess stability conditions as a function of time and depth, on a regional scale, in areas prone to rainfallinduced landslide.

3. Some researchers have focused on parametric analyses to estimate material properties (Salciarini et al., 2006; Vieira, 2010). They proved that reasonable approximations of soil parameters, based on a limited number of measurements in the study area, were able to produce satisfactory results.

4. The TRIGRS model was augmented with a statistical technique. In the probabilistic approach with TRIGRS, the simulated landslide potential map created was generally comparable to field observations when using the 
Monte Carlo simulation (Liu and $\mathrm{Wu}, 2008$ ) and the general extreme value probability distribution (Salciarini et al., 2008).

5. TRIGRS code has been revised and converted for specific purposes. There is a probabilistic version, TRIGRS-P (Raia et al., 2013), and a Matlab version, MaTRIGRS (Liao et al., 2011). TRIGRS-P adopts a stochastic approach to compute and input parameters to be sampled randomly from a given probability distribution. MaTRIGRS offers unique computational efficiency in multi-dimensional matrix data and in realtime visualization of the simulation during modelling.

The shallow landslide often is mobilized into debris flow, and hence it is necessary to conduct a study into the mechanism and factors governing this process using a coupled methodology. Many researchers have previously conducted studies into the debris flow mobilization from shallow landslide by combining the pre-failure and post-failure process using a single model or two different models.

Chiang et al. (2012) proposed a coupled model to simulate landslide-induced debris flow at watershed level. The model combines a landslide susceptibility model to predict landslide, an empirical model to select debris flow initiation points among predicted landslide area and a debris flow model to simulate the spread and inundated region of failed materials from the identified source areas.

Gomes et al. (2013) used the numerical models with an empirical procedure using back analysis data. They conducted landslide and debris flow analysis using the following steps: (a) detection of landslide-susceptible areas from the SHALSTAB model; (b) estimation of rheological parameters of debris flow using back analysis technique; and (c) combination of SHALSTAB and FLO-2-D to model debris flow spreading area. The combination of two physically based models was able to simulate both landslides and debris flow events.

Wang et al. (2013) integrated two major movement modes of slope failure: landslide and debris flow using dynamic process across 3-D terrains. First, the revised Hovland 3-D limit equilibrium model based on a geographic information system (GIS) was used to model the movement and stoppage of a landslide. In this step, they calculated the 3-D factor of safety step by step during the sliding. They defined stoppage for the factor of safety much greater than one and the velocity equal to zero. Also, a GIS-based depth averaged 2-D numerical model was used to predict the inundated area as well as run-out distance of debris flow.

The main objective of this study was to predict shallow, rainfall-triggered landslides using TRIGRS, in the region of Woomyeon Mountain. The landslide ratio of each predicted class of safety factors was employed in evaluating the performance of the landslide model. Finally, this paper discusses the applicability of the flow routing model and then

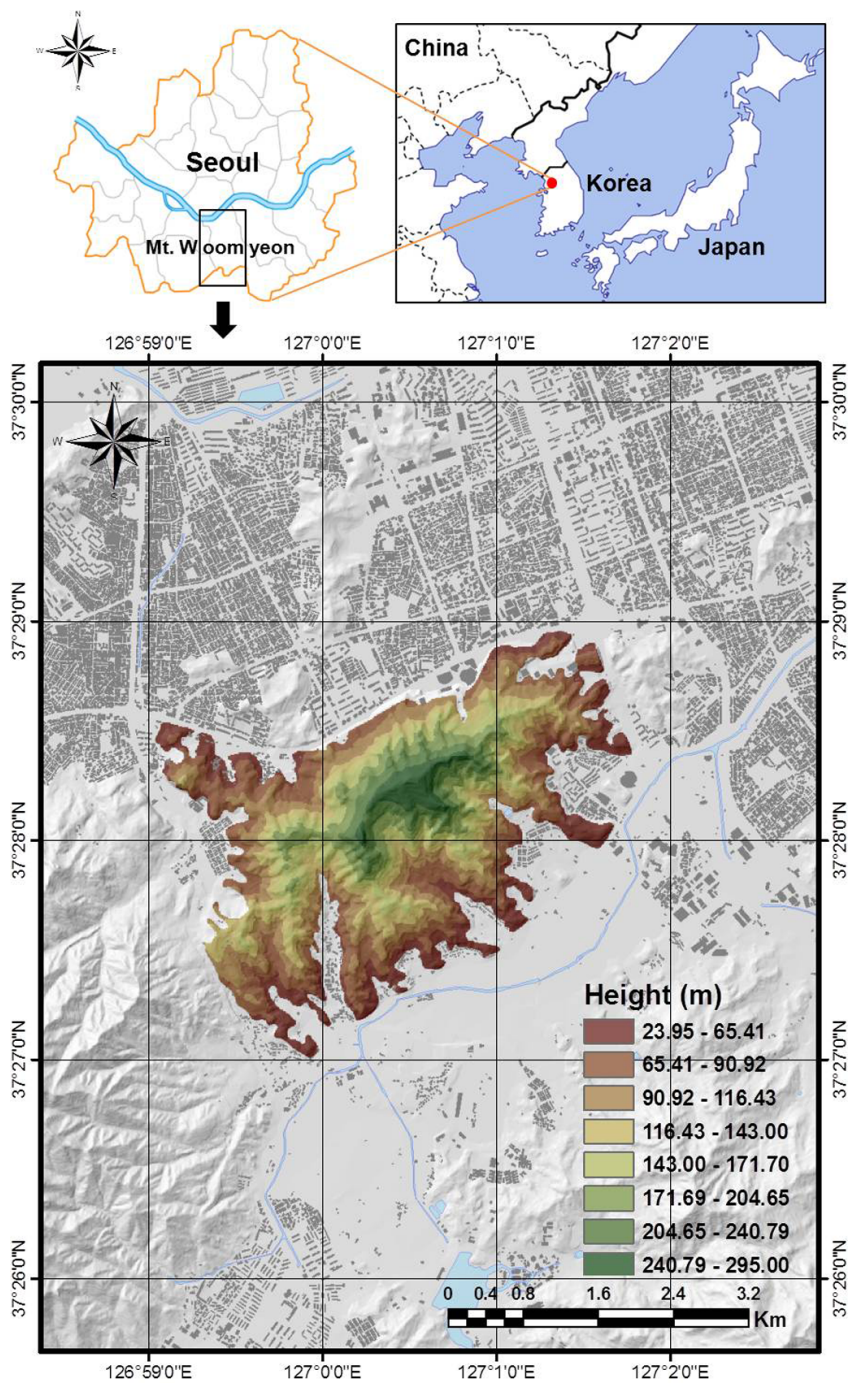

Fig. 1. Location map of the Mt. Woomyeon region in South Korea.

concludes with a discussion of the effectiveness of this approach and the potential for further research.

\section{Study area}

The study area was Woomyeon Mountain, which is located in the Seocho district of Seoul City, South Korea (Fig. 1). It is located at $37^{\circ} 27^{\prime} 00^{\prime \prime}-37^{\circ} 28^{\prime} 55^{\prime \prime} \mathrm{N}$ latitude and $126^{\circ} 59^{\prime} 02^{\prime \prime}$ $127^{\circ} 01^{\prime} 41^{\prime \prime} \mathrm{E}$ longitude. The elevation of Woomyeon Mountain is $293 \mathrm{~m}$ above sea level. Completely encircled by buildings and roads, this area measures $5104162 \mathrm{~m}^{-2}$ and is predominantly covered by forest, mostly oak trees.

The Mt. Woomyeon range is basically composed of preCambrian banded biotite gneiss and granitic gneiss as depicted in Fig. 2. The banded biotite gneiss is moderately weathered and has stripes called gneissic banding, which develops under conditions of high temperature and pressure. 


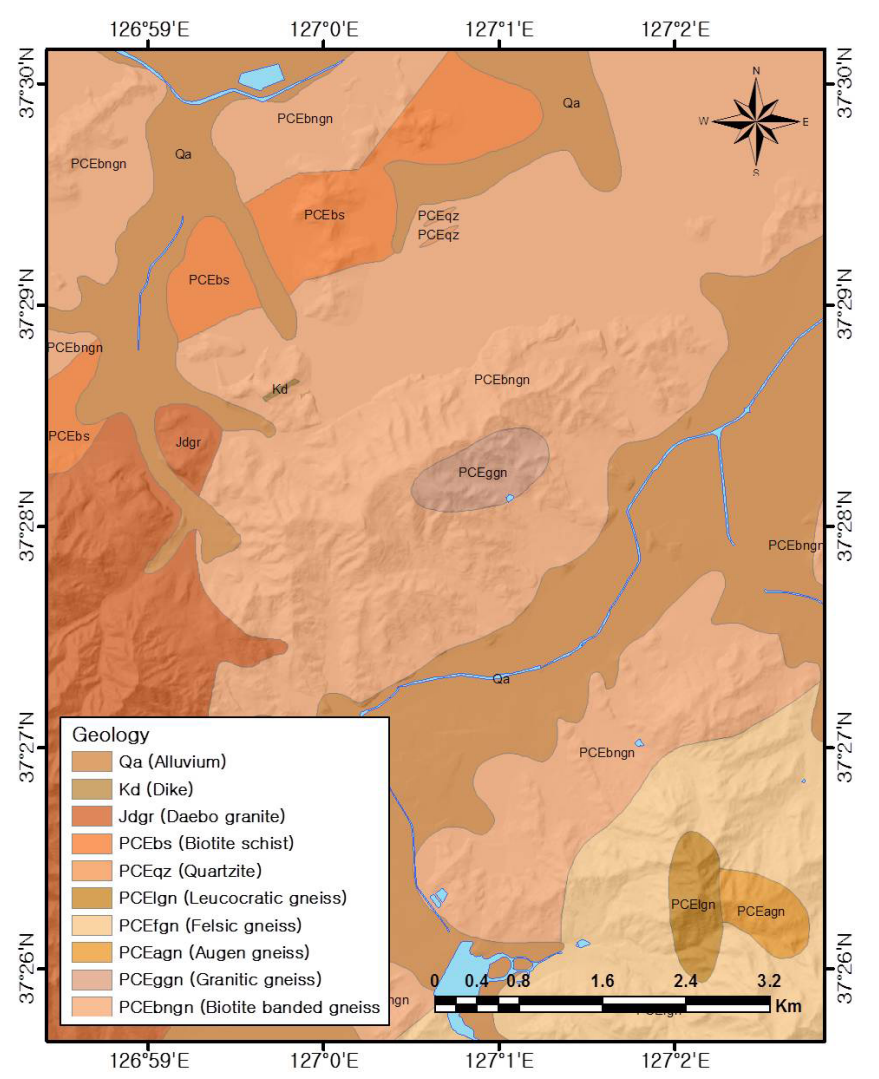

Fig. 2. Geological map of the study area.

Because of the gneissic banding, it is clear that the study area has been exposed to extreme shearing.

The soil profile can be divided into three main layers (Korean Geotechnical Society, 2011):

1. A colluvium layer extends to a maximum depth of $3.0 \mathrm{~m}$ from the ground level, and the upper part of this layer was formed from previously transported soil. This layer is generally loose material composed of gravel and silty sand, according to the Unified Soil Classification System (USCS), a heterogeneous, incoherent and permeable soil.

2. A transition zone is composed of mainly a clay layer (thickness is $0.2 \mathrm{~m}$ to $0.5 \mathrm{~m}$ below colluvium layer) characterized by the colours taupe and dark brown. It was anticipated that landslides would be generated by conditions in this layer between the colluvium and bedrock.

3. A subsoil of stiff weathered bedrock is followed by a clay layer. This subsoil layer can be considered impervious according to the low hydraulic conductivity indicated by the modelling that follows.

\section{Landslide event}

In the area of Mt. Woomyeon, about 147 catastrophic, shallow, landslide events were triggered by localized torrential rainfall from 26 to 27 July in 2011. News and interviews with local residents and county authorities in the government reports indicate that most of the debris flow occurred in the study area between 08:00 and 09:00 UTC, on 27 July 2011. Most of the landslides were accompanied by debris flows, and mixtures of debris flowed down the roadways into local communities. Sixteen people were killed and ten buildings were damaged by the debris, leading to economic losses of about USD 15 million. Figure 3 depicts the locations of the damaged districts (deaths, buildings, inundated areas, landslide scarps and landslide areas) after the disaster.

Figure 4 contains all the landslides and debris flows documented for this event on 27 July 2011. These have been registered in an official archive of disaster survey reports and publications for the government of Seoul by the Korean Society of Civil Engineers. To recognize shallow landslides, satellite images and aerial photographs taken after landslide events, as well as during field surveys, were used to describe the geomorphic features of the landslide area spatially. Figure $3 \mathrm{a}$ depicts landslide and debris flow locations, and this image is suitable for identifying and mapping the landslides of Fig. 4a. The landslide map identified 147 individual landslides with a landslide density of 29 landslides $\mathrm{km}^{-2}$. Most of the landslides were transformed into translated debris flows as plotted in Figs. 3 and 4.

\section{Theoretical basis}

\subsection{Description of the TRIGRS model}

TRIGRS (Baum et al., 2008) models rainfall infiltration, resulting from storms that have durations ranging from hours to a few days. To do so, it uses analytical solutions of partial differential equations that represent one-dimensional, vertical flow in isotropic, homogeneous materials for either saturated or unsaturated soil conditions (Fig. 5). This combines the theoretical bases of the models for infiltration and subsurface flow of storm water, routing of runoff, and slope stability, to calculate the effects of rainfall on the analysis of stability over large areas. Following is a brief description of the models and formulas used by TRIGRS to represent these processes.

\subsubsection{Infiltration model}

The infiltration models in TRIGRS for initial wet conditions are based on Iverson's linearized solution of the Richards equation and extensions by Baum et al. $(2002,2008)$ to that solution. TRIGRS also uses a series of Heaviside step functions to implement Iverson's suggested summation of his original solution for rainfall of constant intensity, to represent 


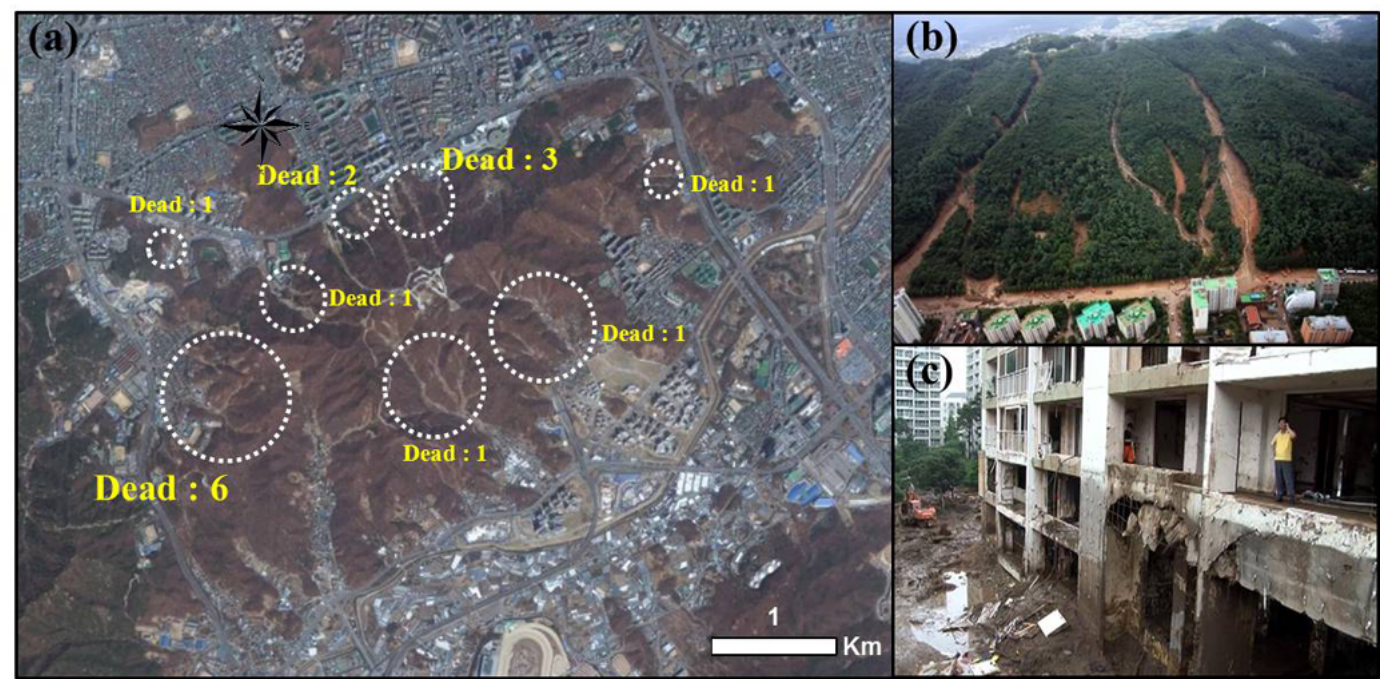

Fig. 3. Overview of landslide events on 27 July 2011: (a) the number of deaths in each region, (b) debris flow hazards, and (c) damaged apartments.

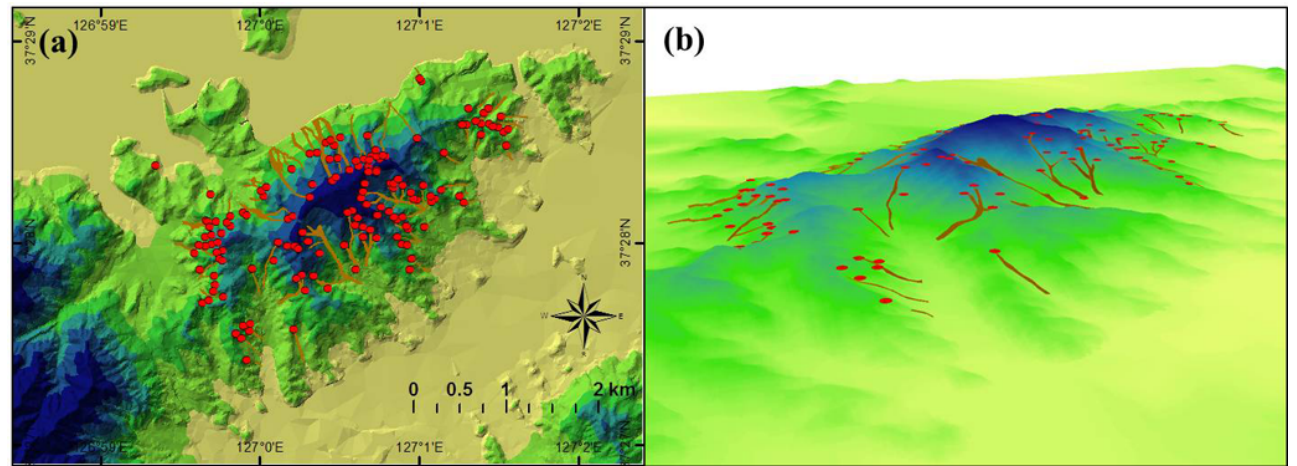

Fig. 4. Landslides and debris flows in the study area: (a) landslide and debris flow mapping and (b) three-dimensional plot of landslide and debris flow.

a general time-varying sequence of surface fluxes of variable intensities and durations. As an alternative to the solution with an infinitely deep basal boundary, Baum et al. (2002, 2008) added to TRIGRS a solution for pore pressure in the case of an impermeable basal boundary at a finite depth $d_{\mathrm{LZ}}$. The pore pressure for an impermeable basal boundary at a finite depth is given by

$$
\begin{aligned}
& \psi(Z, t)=(Z-d) \beta \\
& +2 \sum_{n=1}^{N} \frac{I_{n Z}}{K_{\mathrm{S}}} H\left(t-t_{n}\right)\left[D_{1}\left(t-t_{n}\right)\right]^{\frac{1}{2}} \\
& \sum_{m=1}^{\infty}\left\{\operatorname{ierfc}\left[\frac{(2 m-1) d_{\mathrm{LZ}}-\left(d_{\mathrm{LZ}}-Z\right)}{2\left[D_{1}\left(t-t_{n}\right)\right]^{\frac{1}{2}}}\right]+\operatorname{ierfc}\left[\frac{(2 m-1) d_{\mathrm{LZ}}+\left(d_{\mathrm{LZ}}-Z\right)}{2\left[D_{1}\left(t-t_{n}\right)\right]^{\frac{1}{2}}}\right]\right\}- \\
& +2 \sum_{n=1}^{N} \frac{I_{n Z}}{K_{\mathrm{S}}} H\left(t-t_{n+1}\right)\left[D_{1}\left(t-t_{n+1}\right)\right]^{\frac{1}{2}} \sum_{m=1}^{\infty}
\end{aligned}
$$

$$
\begin{aligned}
& \left\{\operatorname{ierfc}\left[\frac{(2 m-1) d_{\mathrm{LZ}}-\left(d_{\mathrm{LZ}}-Z\right)}{2\left[D_{1}\left(t-t_{n+1}\right)\right]^{\frac{1}{2}}}\right]\right. \\
& \left.+\operatorname{ierfc}\left[\frac{(2 m-1) d_{\mathrm{LZ}}+\left(d_{\mathrm{LZ}}-Z\right)}{2\left[D_{1}\left(t-t_{n+1}\right)\right]^{\frac{1}{2}}}\right]\right\},
\end{aligned}
$$

where $\psi$ is the groundwater pressure head; $Z=z / \cos \delta$, where $Z$ is the vertical coordinate direction (positive downward) and depth below the ground surface; $z$ is the slopenormal coordinate direction (also positive downward), and $\delta$ is the slope angle; $d$ is the steady-state depth of the water table measured in the vertical direction; $d_{\mathrm{LZ}}$ is the depth of the impermeable basal boundary measured in the vertical direction; $\beta=\cos ^{2} \delta-\left(I_{\mathrm{ZLT}} / K_{\mathrm{S}}\right) ; K_{\mathrm{S}}$ is the saturated hydraulic conductivity in the $Z$ direction; $I_{Z L T}$ is the steady (initial) surface flux; $I_{n Z}$ is the surface flux of a given intensity for the $n$th time interval; $D_{1}=D_{0} / \cos ^{2} \delta$, where $D_{0}$ is the saturated hydraulic diffusivity $\left(D_{0}=K_{\mathrm{S}} / S_{\mathrm{S}}\right.$, where $K_{\mathrm{S}}$ is the saturated hydraulic conductivity and $S_{\mathrm{S}}$ is the specific storage); 


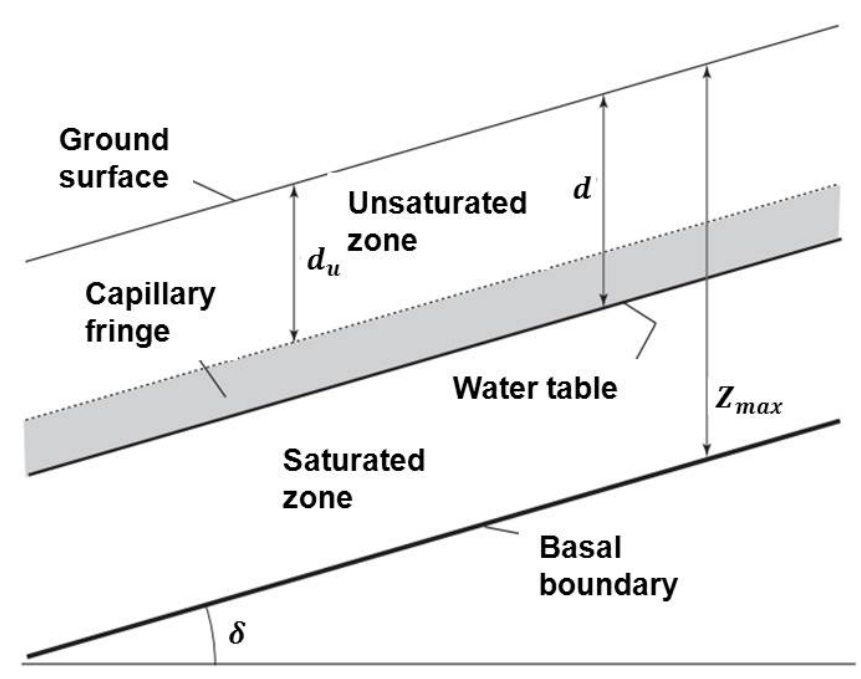

Fig. 5. Conceptual diagram of the TRIGRS model.

$N$ is the total number of time intervals; $H\left(t-t_{n}\right)$ is the Heaviside step function and $t_{n}$ is the time at the $n$th time interval in the rainfall infiltration sequence; $\operatorname{erfc}(\eta)$ is the complementary error function: $\operatorname{ierfc}(\eta)=\frac{1}{\sqrt{\pi}} \exp \left(-\eta^{2}\right)-\eta \operatorname{erfc}(\eta) m$ is index of infinite series displaying an odd term in complementary error function.

\subsubsection{Slope stability model}

The model of slope stability, using an infinite-slope stability analysis, is characterized by the ratio of resisting friction to gravitationally induced downslope driving stress. FS $<1$ denotes unstable conditions, and the depth $Z$ where FS first drops below " 1 " will be the depth of landslide initiation. The equation to calculate the safety factor of the slope according to the infiltration of rainfall for an infinite slope model is given by

$\mathrm{FS}(Z, t)=\frac{\tan \phi^{\prime}}{\tan \delta}+\frac{c^{\prime}-\psi(Z, t) \gamma_{\mathrm{W}} \tan \phi^{\prime}}{\gamma_{\mathrm{S}} Z \sin \delta \cos \delta}$,

where $c^{\prime}$ is soil cohesion for effective stress; $\phi^{\prime}$ is the soil friction angle for effective stress; $\gamma_{\mathrm{W}}$ is unit weight of groundwater; $\gamma_{\mathrm{S}}$ is unit weight of soil.

\subsubsection{Runoff model}

TRIGRS computes the infiltration of each cell. The amount of infiltration, $I$, is the sum of the precipitation, $P$, and runoff from adjacent cells, $R_{u}$, if the infiltration cannot exceed the saturated hydraulic conductivity, $K_{\mathrm{S}}$, as

$I=\begin{gathered}P+R_{u}, P+R_{u} \leq K_{\mathrm{S}} \\ K_{\mathrm{S}}, P+R_{u}>K_{\mathrm{S}} .\end{gathered}$

The runoff, $R_{d}$, is calculated by the following equation:

$R_{d}=\begin{array}{cc}P+R_{u}-K_{\mathrm{S}}, & P+R_{u}-K_{\mathrm{S}} \geq 0 \\ 0, & P+R_{u}-K_{\mathrm{S}}<0 .\end{array}$

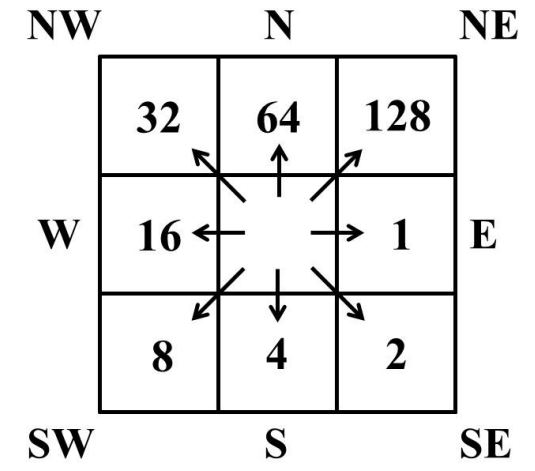

Fig. 6. D8 ESRI direction code overview.

Further theoretical details of the model have been fully described in TRIGRS open file reports (Baum et al., 2002, 2008).

\subsection{Description of the flow routing model}

The model TRIGRS uses a method for routing runoff flow cell by cell in the mass balance calculations. Several methods for the representation of flow directions, using rectangular grid digital elevation models, are presented later, along with flow routing features. Figure 6 shows the designation of the eight flow directions used by following flow routing model, and the numbering scheme according to ESRI direction codes in ArcGIS. This approach is commonly referred to as an eight-direction (D8) flow model because of the eight valid output directions relating to the eight adjacent cells into which flow could travel. Based on the grid DEM, there are many models for predicting the flow.

\subsubsection{The D8 method}

The earliest and simplest method for estimating flow directions is to distribute flow from each cell to one of its eight neighbours, on the steepest downslope path. That is, flow is diverted only to the one neighbouring cell that is on the steepest direction. This model, named the D8 method, was suggested by O'Callaghan and Mark (1984), and has been widely used. In the D8 method approach, however, the resulting flow distribution is irregular and somewhat unrealistic, because flow can occur in only the steepest direction, either adjacent or diagonally, of eight possible directions.

\subsubsection{The multiple flow direction method}

Multiple flow direction method (Quinn, 1991) offers advancement over the D8 method (restricts flow to one among eight possible directions). The fraction of the flow through each grid cell to each downslope direction is proportional to the gradient of each downhill flow path, so that steeper gradients will naturally attract more of the flow. All cells surrounding the central point can be flow directions if they have 


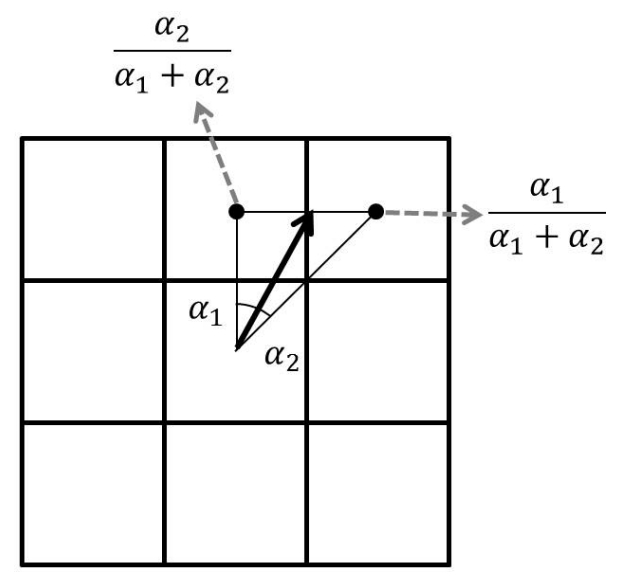

Fig. 7. Concept diagram of D-infinity method.

lower elevations than the initial one. The pattern, of course, becomes more strongly concentrated toward the steepest downslope path. Equation (5) expresses the relative amounts for the downhill directions.

$\Delta A_{i}=A\left(\tan \beta_{i} L_{i}\right) / \sum_{j=1}^{n}\left(\tan \beta_{j} L_{j}\right)$,

where $n$ is the total number of downhill directions; $\Delta A_{i}$ is the amount passed onto the $i$ th downhill cell; $A$ is the total upslope area accumulated in the current cell; $\tan \beta_{i}$ is the gradient (difference in elevation/distance between the elevation values) in the $i$ th downhill directions; $L_{i}$ is the contour length of the $i$ th direction either cardinal or diagonal.

\subsubsection{The D-infinity method}

Tarboton's D-infinity method (Tarboton, 1997) assumes that water flows down one or two cells by partitioning the flow between the two cells nearest to the steepest slope direction. Figure 7 illustrates the calculation of flow directions. The single flow direction is determined by the steepest downwards slope among the eight triangular facets. This direction is calculated by apportioning flow between two downslope pixels according to how close the flow direction is to the direct angle to the downslope pixel. In other words, the procedure is based on representing the flow direction as a single angle taken as the steepest downwards slope among the eight triangular facets. Like for the multiple flow direction method, some dispersion is generated by the proportioning of flow between downslope cells, but this is minimized since flow is never diverted to more than two downslope cells. Compared to other models, the D-infinity method was preferred because it is physically more realistic. The D-infinity method is also used in the program SINMAP.

Table 1 presents a summary of the flow routing methods used in simulations. The TRIGRS runoff module is used to compare the flow direction routing models above, with the observed debris flow routes in the study area.

\section{Application of the model}

\subsection{Rainfall characteristics}

There are two meteorological monitoring stations (Namhyun and Seocho) near the Mt. Woomyeon region. All weather stations are operated by the Korea Meteorological Administration.

The rainfall distribution in the study area is mainly characterized by an average annual rainfall of 1400$1500 \mathrm{~mm}$, which is highest in July and lowest in January. The precipitation conditions occurring in July 2011, however, were significantly different from the average. During July alone, Mt. Woomyeon received about $55 \%$ of its total annual precipitation of $2039 \mathrm{~mm}$. Hourly maximum rainfalls were $114 \mathrm{~mm} \mathrm{~h}^{-1}$ (07:44-08:44 on 27 July) and $87 \mathrm{~mm} \mathrm{~h}^{-1}$ (07:41-08:41 on 27 July). The first record was at Namhyun Station, the second one at Seocho Station. From the intensity-duration-frequency (IDF) curves for Seoul City, the rainfall recurrence intervals were 120 and $20 \mathrm{yr}$, respectively.

Figure 8 shows the hourly rainfall history from 25 July to 27 July in 2011 . Shallow landslides were triggered by the localized torrential rainfall during this period, characterized by a cumulative rainfall of about $350 \mathrm{~mm}$, of which $42 \%$ poured down during the last $2 \mathrm{~h}(06: 00-09: 00)$ before the failures. The landslides started at 09:00 on 27 July.

\subsection{Input parameters}

Many important parameters are involved in the TRIGRS model, for example, topographic factors, soil thickness, as well as strength properties and hydraulic parameters of the soil. Accuracy and reliability of the results depend mainly on detailed knowledge of the study site, and on the quality of the input parameters.

For Mt. Woomyeon, topographic analyses for elevation, slope angle and aspect were calculated from 1:5000 maps developed by the National Geographic Information Institute. ArcGIS was used to create grids with $10 \mathrm{~m}$ cells and to quantify the aforementioned information above for each cell of the DEM.

All available data were obtained from the engineering geological investigation for landslides hazard restoration work conducted by the National Forestry Cooperative Federation, Korean Society of Civil Engineers and Korean Geotechnical Society. After the landslides occurred on 27 July, a total of 58 geotechnical investigation boreholes were drilled for collecting soil, hydrologic and geological information. Among these, available data from 13 boreholes and 19 soil samples were used in this analysis. Based on the wide database, the average values were used. The locations of the investigation boreholes and profiles are depicted in Fig. 9. Determination of the soil water characteristic curve was accomplished by using pressure plate extractor and filter paper method as 
Table 1. Summary of flow routing models.

\begin{tabular}{|c|c|c|}
\hline Flow routing model & Weighting factor in TRIGRS & Symbol \\
\hline $\begin{array}{l}\text { D8 method } \\
\text { (O'Callaghan and Mark, 1984) }\end{array}$ & $\begin{array}{l}w_{i j}=1 ; \text { cell on steepest path } \\
w_{i j}=0 ; \text { other downslope cells }\end{array}$ & \multirow{3}{*}{$\begin{array}{l}i: \text { grid cell } \\
j: \text { each neighbouring downslope cell } \\
n: \text { the number of neighbouring grid } \\
\text { cells } \\
w_{i j}: \text { weighting factors } \\
s_{i j}: \text { a function of the slope } \\
\delta_{i j}: \text { angle between the D8 flow } \\
\text { direction and the steepest slope }\end{array}$} \\
\hline $\begin{array}{l}\text { Multiple flow direction method } \\
\text { (Quinn, 1991) }\end{array}$ & $w_{i j}=s_{i j}^{w} / \sum_{j=1}^{j=n} s_{i j}^{w}$ & \\
\hline $\begin{array}{l}\text { D-infinity method } \\
\text { (Tarboton, 1997) }\end{array}$ & $\begin{array}{l}w_{i 1}=\left(\frac{\pi}{4}-\delta_{d}\right) /\left(\frac{\pi}{4}\right), w_{i 2}=\delta_{d} /\left(\frac{\pi}{4}\right) \\
; \text { if two cells } \\
w_{i 1}=1 ; \text { if only one cell }\end{array}$ & \\
\hline
\end{tabular}

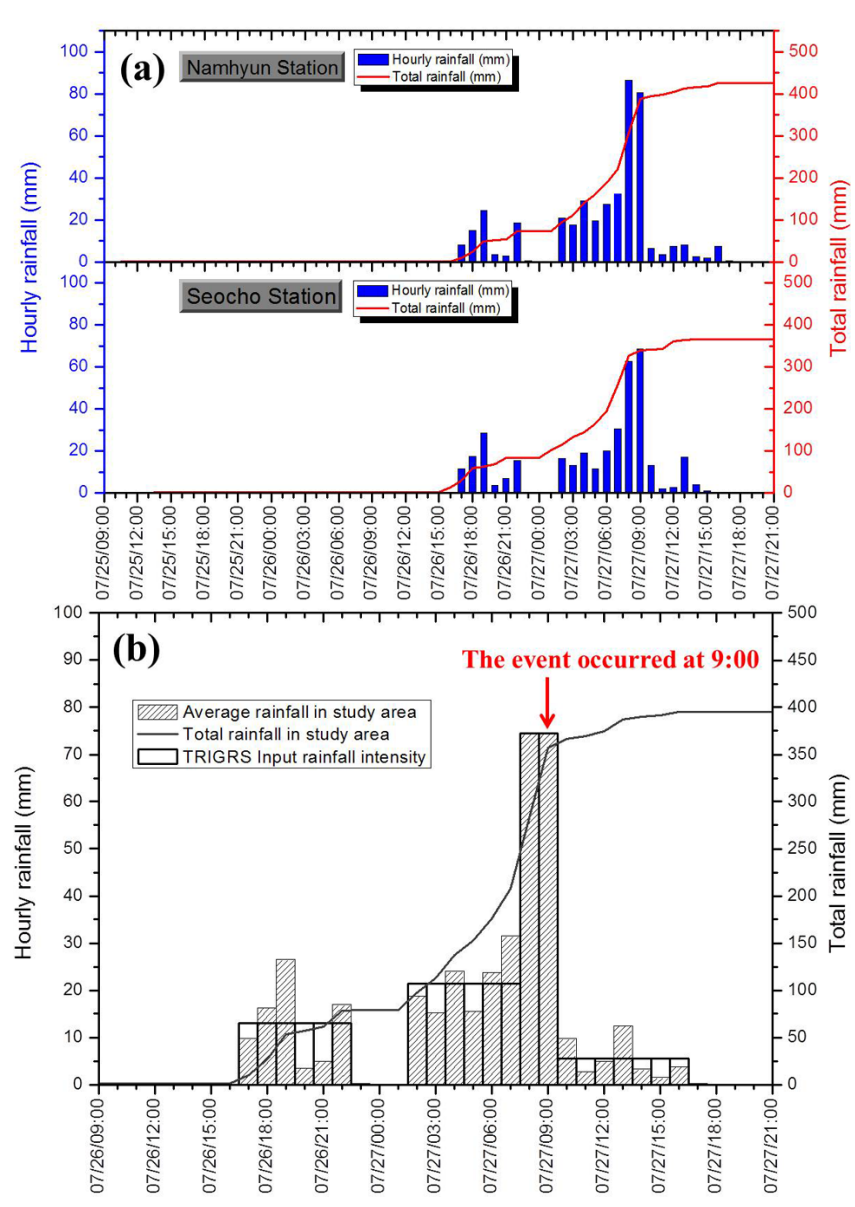

Fig. 8. Hourly and total rainfall distribution on 25-27 July 2011: (a) rainfall at Namhyun and Seocho stations and (b) TRIGRS input rainfall intensity.

shown in Fig. 10. Using van Genuchten formula yielded best fits among several fitting equations. From the soil-water retention curves, saturated and residual volumetric water content were $50 \%$ and $18 \%$, respectively.

Hydraulic parameters including hydraulic saturated conductivity $\left(K_{\mathrm{S}}\right)$, diffusivity $\left(D_{0}\right)$ and steady infiltration rate $\left(I_{Z}\right)$ were obtained from laboratory tests, and derived

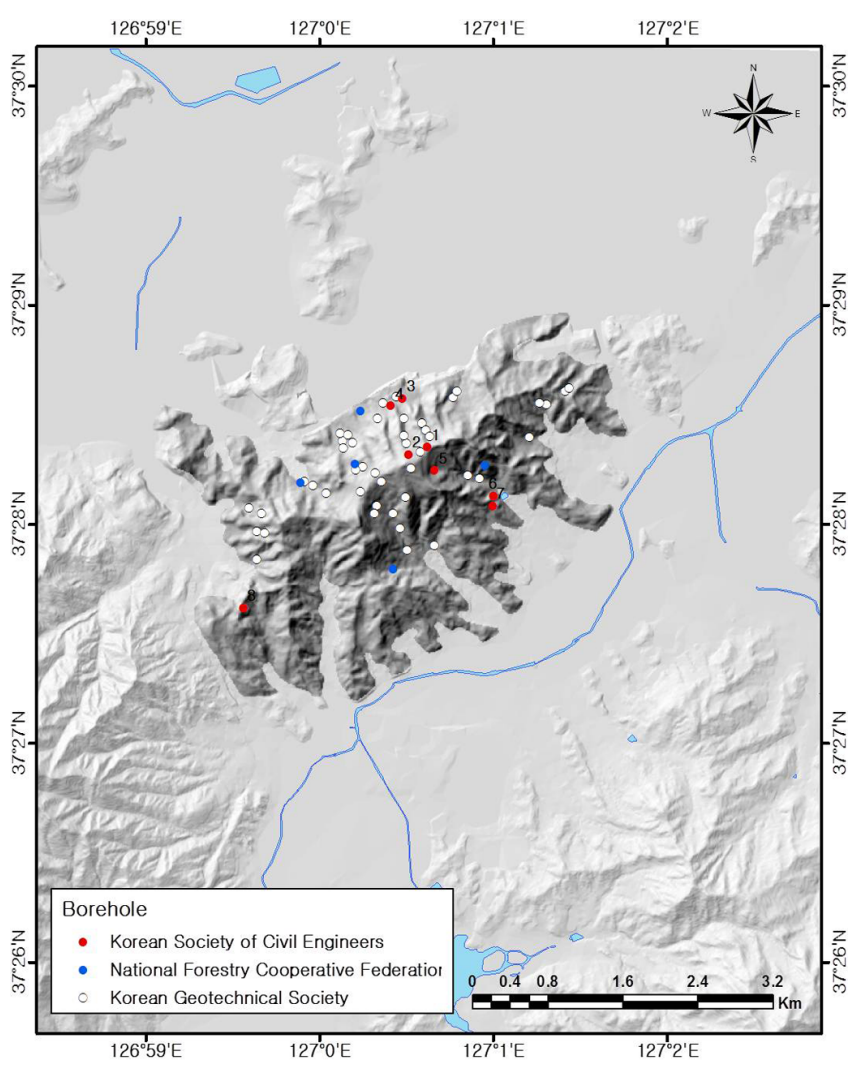

Fig. 9. Locations of investigation boreholes and sampling positions.

according to soil classes and empirical references. The values of $D_{0}$ and $I_{Z}$ were not well defined, since they had wide ranges according to the complex properties of soil (e.g. void, fine content, and soil density). These parameters are quite different for various samples, even though they were collected from the same site. In a literature review about colluvium soil, $D_{0}$ was discovered to have a value about $10-500$ times the value of the hydraulic conductivity. For this reason, the $D_{0}$ value was assumed to be 200 times the $K_{\mathrm{S}}$ (Liu and $\mathrm{Wu}, 2008$ ). Information about the $I_{Z}$ rate, however, is rare in the literature. The $I_{Z}$ value is affected by soil characteristics including porosity, storage capacity, and transmission 


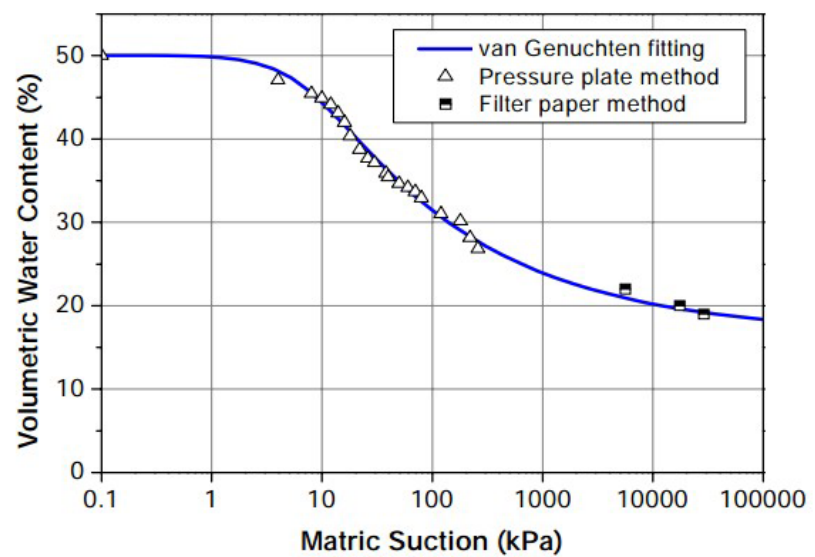

Fig. 10. Soil water characteristic curve in study area.

rate through the soil. The soil texture and structure, vegetation types and cover, water content of the soil and soil temperature also play a role in controlling the infiltration rate. If the soil is saturated, $I_{Z}$ can be the same as hydraulic conductivity, while it can be zero for dry soil. In this research, the reasonable value 0.01 of the $K_{\mathrm{S}}$ (Salciarini et al., 2008; Liu and Wu, 2008; Kim et al., 2010) was selected for $I_{Z}$ because of the hot, dry conditions during the summer of this event.

In the simulations carried out in this study, a uniform soil depth of $2 \mathrm{~m}$ was considered based on site investigation reports (Korean Geotechnical Society, 2011), and it conforms to several studies which show that most of shallow landslides in the mountainous regions of South Korea are observed between 1 and $3 \mathrm{~m}$. The initial groundwater table is set at the same depth of soil thickness due to no heavy antecedent rainfall before the event and hot dry conditions during the summer of this event (Kim et al., 2010).

The input values, and units of the parameters for analysis, are listed in Table 2.

\subsection{Debris flow routing module}

The runoff routing module is an optional flow routing algorithm embedded in the TRIGRS model. The analysis time with runoff calculation is almost the same as without runoff calculation analysis case, since the module requires small computational effort.

ArcGIS was used for the preparation of the input data DEM and DIRECTION needed for runoff routing in TRIGRS. This is because the input parameters need to be constructed into a spatial database in a GIS platform. The next step involves the determination of the flow distribution weighting factors. By changing the weighting factor, the user can control the width of flow and direction algorithms as mentioned previously (Table 1). Once a topographic data set and routing method are selected for a study area, the maximum number of iterations is set up to apply the runoff
Table 2. Summary of values used in simulations.

\begin{tabular}{lr}
\hline Parameter (unit) & Value \\
\hline Friction angle, $\phi\left(^{\circ}\right)$ & 29.63 \\
Cohesion, $c(\mathrm{kPa})$ & 10.17 \\
Total unit weight of soil, $\gamma_{\mathrm{S}}\left(\mathrm{KN} / \mathrm{m}^{3}\right)$ & 18.38 \\
Hydraulic conductivity of saturated, $K_{\mathrm{S}}\left(\mathrm{m} \mathrm{s}^{-1}\right)$ & $1.3 \times 10^{-5}$ \\
Saturated volumetric water content, $\theta_{\mathrm{S}}$ & 0.5 \\
Residual volumetric water content, $\theta_{\mathrm{r}}$ & 0.18 \\
Hydraulic diffusivity, $D_{0}\left(\mathrm{~m}^{2} \mathrm{~s}^{-1}\right)$ & $200 K_{\mathrm{S}}$ \\
Steady infiltration rate, $I_{Z}\left(\mathrm{~m} \mathrm{~s}^{-1}\right)$ & $0.01 K_{\mathrm{S}}$ \\
\hline
\end{tabular}

module. The reason for setting the maximum number of iterations is to allow the module to stop after a reasonable time period, because in the case of DEM it is not hydrologically consistent and sometimes it cannot converge.

Further details of the module have been fully described in TRIGRS open file reports (Baum et al., 2002, 2008).

\section{Results and discussion}

\subsection{Elevation, slope, aspect and curvature}

The simulations described below were carried out at two levels: (i) considering landslides of the study area where 147 shallow landslides occurred during an intense rainfall event in July 2011, and (ii) taking into account the debris flow routes, but not debris mass, velocity and deposits.

In the study area, elevation, slope, aspect and curvature, all of which are relevant to landslides, were calculated from topographic information. These results for both the study area and the landslide occurrence points are shown in Fig. 11. Bar graphs represent the percentage of the area of each category, in relation to the total study area. Polygonal lines are the ratio of the number of landslides in each category, in relation to the total number of landslides.

Seventy percent of the study area was between $50 \mathrm{~m}$ and $150 \mathrm{~m}$ elevation, and $67 \%$ of the slope angles were between 10 and 25 degrees. Most of the landslides were triggered on terrain with mid- to high altitudes ranging from 100 to $250 \mathrm{~m}$ (average $119 \mathrm{~m}$ ), and on steeper slopes $\left(>25^{\circ}\right.$, average slope angle of the study area: $\left.19^{\circ}\right)$. The aspect ratios in each category were similar to each other while the largest landslide orientation was east with $18 \%$. Curvature graph showed nearly the same number of concave and convex profiles in the study area, but concave was predominant in failure spots.

\subsection{Prediction of landslides}

One main objective of this research is to evaluate the spatiotemporal predictability of landslide events in Mt. Woomyeon using the TRIGRS model for regional landslide hazard 

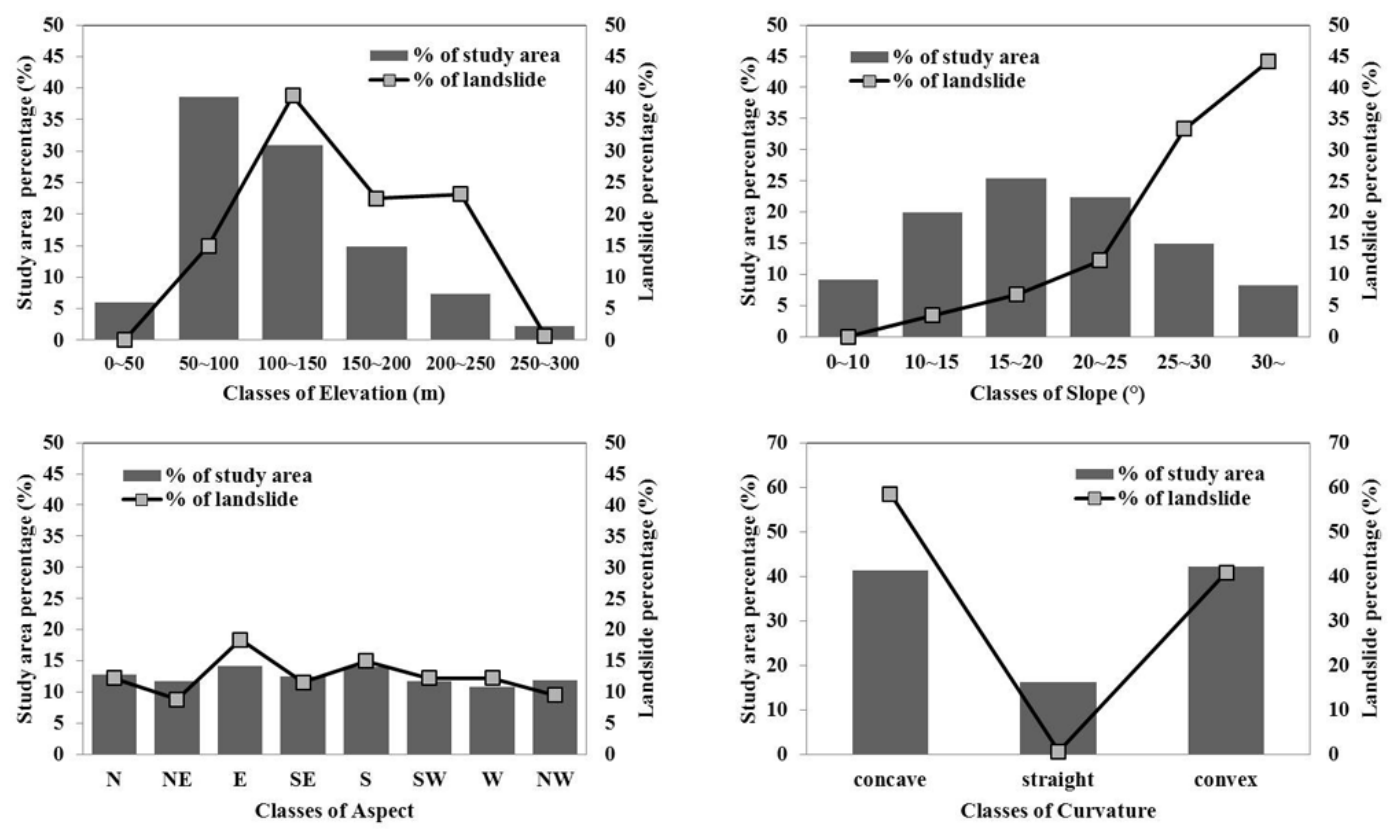

Fig. 11. Factor of safety (FS) at different times in the study area.

assessment. The factor of safety (hereafter FS) over the entire study area was calculated for each cell, and plotted over time during this severe storm. Figure $12 \mathrm{a}, \mathrm{b}$ and $\mathrm{c}$ show the spatial distributions of FS in different periods of time. In other words, these depict the temporal and spatial dynamics of FS values induced by heavy rainfall during the $48 \mathrm{~h}$ duration (from 09:00, 25 July to 09:00, 27 July). The three FS maps are for 0,46 , and $48 \mathrm{~h}$, and $46 \mathrm{~h}$ corresponded to the start of extraordinarily heavy rainfall for $2 \mathrm{~h}$. The TRIGRS model correctly simulated the time that the landslides were triggered. The areas characterized as having a safety factor close to $\mathrm{FS}=1.0$ progressively expanded when the rainfall became more intense. This implies that large numbers of the landslides were triggered by the intense rainfall. The Korean peninsula has a lot of curvy and steep nature of mountainous terrain. This is why FS maps are very complex and tortuous. Nevertheless, the performance of the TRIGRS model for prediction, which has been evaluated by field investigation, can be considered reasonably applicable as shown in Fig. 12c.

The success of landslide prediction models has been typically evaluated by comparing locations of measured landslides with the predicted results. Thus, a proper index or an estimator for measuring performance is essential. Most previous studies (Crosta et al., 2003; Salciarini et al., 2006; Kim et al., 2010; Vieira et al., 2010;) used agreement of parts (cells) between the predicted and the actual landslides to evaluate the performance of their models.

However, it can be seen that the model output with more unstable areas is better than the underestimated results, since it covers more landslides. An ideal landslide assessment model simultaneously maximizes the agreement between known and predicted locations of landslides, and minimizes predicted unstable area to give useful information for prediction. In order to overcome the disadvantages and limitations of such comparisons, various indices have been proposed: SR and MSR stand for success rate and modified success rate (Huang and Kao, 2006); ROC stands for receiver operating characteristic using confusion matrix (Godt et al., 2008; Montrasio, 2011; Raia et al., 2013); SI and EI stand for success index and error index (Sorbino et al., 2010); SC and LP stand for scar concentration and landslide potential (Vieira et al., 2010); POD, FAR and CSI stand for probability of detection, false alarm ratio and critical success index (Liao et al., 2011); and the D index (Liu and $\mathrm{Wu}, 2008$ ).

Although the performance indices above are useful for quantifying the effectiveness of a model, the precise area of known landslides is necessary for applying them. In the Mt. Woomyeon event, it is difficult to know the size of the landslides that occurred, since a number of the debris flows occurred after the landslides. Figure 4a depicts this problem associated with unclear boundaries of landslides. Most landslide areas are connected with debris flow channels. This is the reason why counting landslide sites, instead of calculating landslide area, was used in the following.

In this paper, the landslide ratio of each predicted FS class (hereafter $L_{\text {class }}$ ) was employed for evaluating the performance of the landslide model. $\mathrm{LR}_{\text {class }}$ was based on the ratio of landslide sites contained in each FS class, in relation to the total number of actual landslide sites (total 147 spots), according to the predicted percentage of area in each class of FS category. 

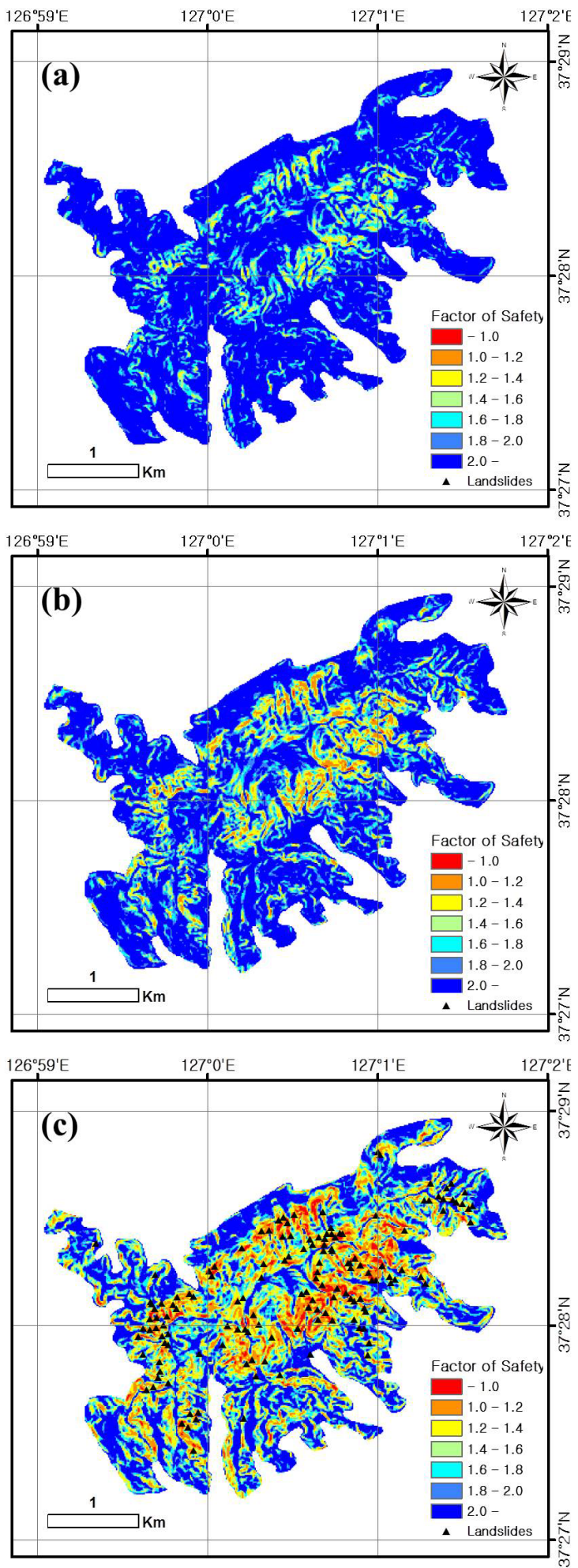

Fig. 12. Classes of topographic parameters (elevation, slope angle, aspect and curvature) for (a) $0 \mathrm{~h}(09: 00,25$ July 2011), (b) $46 \mathrm{~h}$ (07:00, 27 July 2011), and (c) 48 h (09:00, 27 July 2011).

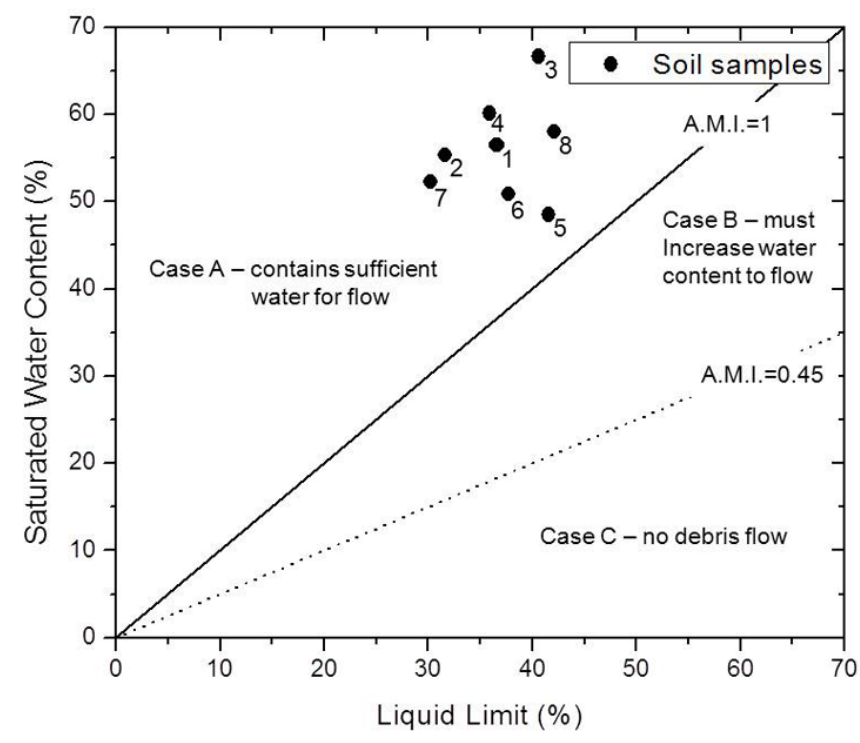

Fig. 13. Relationship between saturated water content and liquid limit of soil samples. Numbers identify samples in Table 3: (a) percentage of predicted FS and landslide and (b) percentage of $\mathrm{LR}_{\text {class }}$.

$\mathrm{LR}_{\text {class }}=\frac{\% \text { of contained landslide sites in each class of } \mathrm{FS}}{\% \text { of predicted landslide areas in each class of } \mathrm{FS}}$.

Note that in the numerator, the number of landslide sites, instead of the number of landslide cells, is used because of the difficulty in defining boundaries between landslides and debris flows. The performance value derived by $\mathrm{LR}_{\text {class }}$ enables consideration of predicted stable areas as well as predicted unstable areas, and thus substantially reduces the overprediction of landslide potential. Unlike the numerator, the number of predicted and total cells is used in the denominator. The numerator, also, is the same as the SR (success ratio) index.

Table 4 and Fig. 14 show that $2.99 \%$ of the area was classified as unstable $(\mathrm{FS} \leq 1.0)$, and that $33.33 \%$ of the actual landslides were correctly localized within this predicted unstable area. $\mathrm{LR}_{\mathrm{FS}<1}$ was about 11 with $33.33 \%$ over $2.99 \%$. By calculating the $\%$ of $\mathrm{LR}_{\text {class }}$, we can get a quantitative result. The percentage of $L R_{F S<1}$ is $70.30 \%$; in other words, if a landslide happens, then the predicted unstable area $(\mathrm{FS}<1)$ has $70.30 \%$ chance of including the landslide. Also, lower safety factor classes showed higher values of $\mathrm{LR}_{\text {class }}$ percentages. The results show significant agreement between the simulated and known landslide map from a quantitative point of view, despite missing information on landslide area.

\subsection{Prediction of debris flow routes}

During severe storms, the failed soil mass rapidly propagates downslope and increases its initial volume through erosion of in-place soils producing a dangerous mobilized volume 
Table 3. Summary of geotechnical laboratory results. CL is Lean clay, SC is Clayey sand and SM is Silty sand.

\begin{tabular}{|c|c|c|c|c|c|c|c|c|c|c|}
\hline \multirow[t]{2}{*}{$\begin{array}{l}\text { No. in } \\
\text { Figs. } 9 \text { and } 13\end{array}$} & \multirow[t]{2}{*}{$\begin{array}{c}\text { Water } \\
\text { content }(\%)\end{array}$} & \multirow[t]{2}{*}{$\begin{array}{l}\text { Specific } \\
\text { gravity }\end{array}$} & \multicolumn{2}{|c|}{$\begin{array}{l}\text { Atterberg } \\
\text { limit }\end{array}$} & \multicolumn{4}{|c|}{$\begin{array}{c}\text { Sieve analysis } \\
(\%)\end{array}$} & \multirow[t]{2}{*}{ USCS } & \multirow[t]{2}{*}{$\begin{array}{r}\text { Saturated water } \\
\text { content }(\%)\end{array}$} \\
\hline & & & LL & PI & \#4 & \#10 & $\# 40$ & \#200 & & \\
\hline 1 & 18.2 & 2.73 & 36.6 & 15.4 & 100 & 99.3 & 85.5 & 51.9 & CL & 56.5 \\
\hline 2 & 14.1 & 2.71 & 31.6 & 9.3 & 75.0 & 72.2 & 57.5 & 28.9 & $\mathrm{SC}$ & 55.4 \\
\hline 3 & 32.1 & 2.64 & 40.6 & 16.9 & 98.3 & 96.2 & 81.9 & 55.7 & $\mathrm{CL}$ & 66.7 \\
\hline 4 & 15.8 & 2.74 & 35.9 & 15.0 & 98.7 & 95.8 & 76.6 & 44.4 & $\mathrm{SC}$ & 60.1 \\
\hline 5 & 21.2 & 2.64 & 41.6 & 18.6 & 87.6 & 85.9 & 74.2 & 55.1 & CL & 48.5 \\
\hline 6 & 28.2 & 2.64 & 37.7 & 14.2 & 98.7 & 95.3 & 77.0 & 55.8 & CL & 50.9 \\
\hline 7 & 28.1 & 2.65 & 30.2 & 6.4 & 84.4 & 81.3 & 62.1 & 28.8 & SM & 52.3 \\
\hline 8 & 30.6 & 2.66 & 42.1 & 19.1 & 100 & 96.8 & 71.7 & 54.2 & CL & 58.0 \\
\hline
\end{tabular}

Table 4. Summary of TRIGRS results in landslide simulations

\begin{tabular}{lrrrrr}
\hline $\begin{array}{l}\text { Safety factor } \\
\text { classes }\end{array}$ & $\begin{array}{r}\text { Landslide site } \\
(a)\end{array}$ & $\begin{array}{r}\text { \% of landslide } \\
\text { site }(c)=a / b\end{array}$ & $\begin{array}{r}\text { \% of predicted } \\
\text { area }(d)\end{array}$ & $\begin{array}{r}\mathrm{LR}_{\text {class }} \\
(e)=c / d\end{array}$ & $\begin{array}{r}\text { \% of } \mathrm{LR}_{\text {class }} \\
=e / f\end{array}$ \\
\hline $\mathrm{FS} \leq 1.0$ & 49 & 33.33 & 2.99 & 11.14 & 70.30 \\
$1.0<\mathrm{FS} \leq 1.2$ & 59 & 40.14 & 13.68 & 2.93 & 18.51 \\
$1.2<\mathrm{FS} \leq 1.4$ & 13 & 8.84 & 14.76 & 0.60 & 3.78 \\
$1.4<\mathrm{FS} \leq 1.6$ & 11 & 7.48 & 15.87 & 0.47 & 2.97 \\
$1.6<\mathrm{FS} \leq 1.8$ & 6 & 4.08 & 10.77 & 0.38 & 2.39 \\
$1.8<\mathrm{FS} \leq 2.0$ & 3 & 2.04 & 10.53 & 0.19 & 1.22 \\
$2.0<\mathrm{FS}$ & 6 & 4.08 & 31.39 & 0.13 & 0.82 \\
\hline Sum & $147(b)$ & 100.00 & 100.00 & $15.85(f)$ & 100.00 \\
\hline
\end{tabular}

called a debris flow. A large number of landslides evolved into debris flows during the torrential rainfall from 26 to 27 July 2011, in Seoul, South Korea. The average length of debris flows in the study area was about $317.0 \mathrm{~m}$, with an average volume of $269 \mathrm{~m}^{3}$. The biggest debris flow mapped has a length of $632 \mathrm{~m}$ while the smallest is less than several tens of metres (Korean Society of Civil Engineers and Korean Geotechnical Society, 2012).

In this study, we suggested a debris flow routing method for the TRIGRS runoff module. This concept aims at giving a prompt assessment of debris flow path analysis at a regional scale with minimum data requirement. Most debris flow susceptibility models obviously depend on a lot of information about the area of interest. Due to the complexity of debris flows relative to the modelling parameters, a simplified model was required for predicting flow paths on a regional scale.

The ability to predict debris flow using the runoff module of TRIGRS can be important for two purposes: to gain landslide-induced debris flow susceptibility zonation and to apply the processes for debris flows that are generated through runoff and erosion.

The TRIGRS runoff module is more suitable for cases which have high debris flow potential since the module detects every susceptibility region of debris flow. The likelihood for a landslide to mobilize into a debris flow has been assessed in various approaches. These methods use geotechnical properties such as porosity, permeability and grain size distribution (Iverson et al., 2000; Ellen and Fleming, 1987) and morphological features such as channel gradient, curvature and volume (Takahashi, 1981; Horton et al., 2011) controlling whether a landslide will mobilize into a flow or not.

Among them, Johnson and Rodine (1984) devised a mobility index (MI), which is the ratio of saturated water content of the in-place soil to water content of the soil necessary to flow in a specific channel. They found that debris flow was more likely to occur in the case of $\mathrm{MI}>0.85$, while $\mathrm{MI}<0.85$ did not produce any debris flows. Furthermore, Ellen and Fleming (1987) introduced the approximate mobility index (here after AMI) by using the liquid limit. Qualitatively, the liquid limit seems appropriate for representing the flow process since it is the water content that soil behaviour is resembling marginally fluid behaviour under shallow conditions. The AMI is defined as the ratio of in situ saturated water content to the water content at the liquid limit. In the case of AMI > 1 (case A) that plots above the solid line in Fig. 13, the soils would flow easily when remolded. This is because these soils have initial capacity to hold more water than their liquid limits and also have low shear strength. Soils 

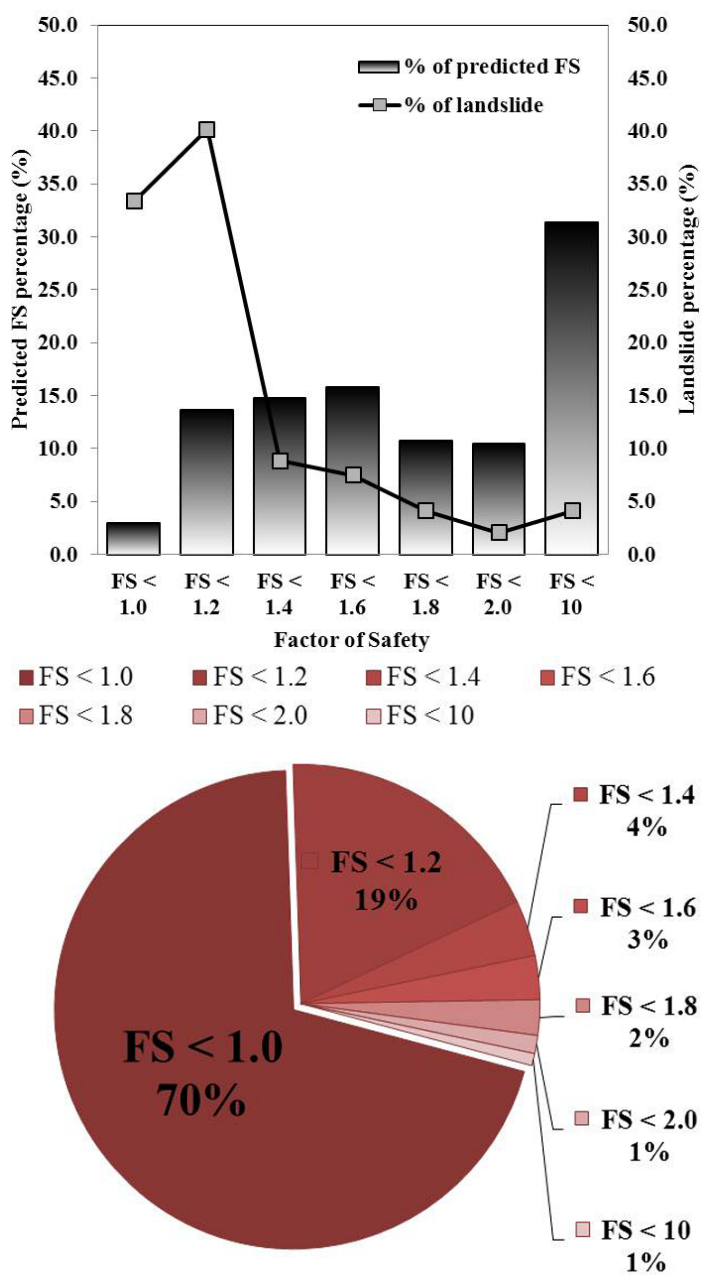

Fig. 14. Results obtained by TRIGRS in each class.

with $\mathrm{AMI}<1$ must dilate in order to increase initial water capacity beyond the liquid limit. Zone B $(0.45<$ AMI $<1)$ represents that soils need more water for flowing at least in parts of slide masses while zone C (AMI < 0.45) apparently could not be mobilized into debris flow.

In the study area, geotechnical laboratory results to calculate the AMI are tabulated in Table 3. The AMI of the soil samples in the study area is plotted in Fig. 13. Every soil plotted above the solid line (AMI > 1) means debris flow mobilized from shallow landslide. It is inferred that the overall study area is vulnerable to landslide-induced debris flow based on the AMI results. In conclusion, the application of the runoff module enables proper a debris flow analysis in the case of the Mt. Woomyeon event.

Moreover, the use of the runoff module can be extended to the analysis of debris flow generated by runoff. Debris flows, also, are able to be initiated by mobilization of a channel bed due to surface water flow (Takahashi, 1991; Iverson, 1997). The surface water runoff erodes and entrains hillslope and channel materials (Larsen et al., 2006), and thus surface runoff is also an important process in high mountainous regions due to the concentration of overland flow upstream of the source areas (Berti et al., 1999). The TRIGRS runoff module provides the amount of runoff discharge considering infiltration and flow direction. Thus, by using this module, it was possible to provide a quick, simple preliminary debris flow assessment induced by both shallow landslide and runoff, according to the different field conditions. Runoffinduced debris flow is more frequent in semi-arid to arid mountainous regions which consist of water-repellent soils that can result in significant reduction of infiltration (Coe et al., 2008b).

The initiation mechanisms of the runoff-generated debris flows are different from debris flows initiated by the mobilization of landslides (Iverson, 1997), and some of studies have used simple models for predicting runoff-induced debris flow (Gregoretti, 2000; Tognacca et al., 2000). These hydrologic models suggested to be capable of predicting the surface runoff discharge sufficient to produce debris flow are influenced by various input parameters depending on slope angle, grain size, unit weight of soil, water supply and so on. More generally, it would be described by a threshold criterion relating to runoff discharge (or flow height) with specific material properties and channel slope (Berti and Simoni, 2005; Coe et al., 2008a). However, a comprehensive debris flow initiation threshold is still lacking due to the complexity of the problem and the many unknown parameters.

A critical surface runoff discharge could be required before the process of bed mobilization starts and a debris flow is initiated. Coe et al. (2008b) suggested that the minimum amount of specific runoff discharge required to generate debris flow is about $0.075 \mathrm{~m}^{3} \mathrm{~s}^{-1}$ for the chalk cliffs of central Colorado. Although most of debris flow was generated by shallow landslides on Mt. Woomyeon, the value of $0.075 \mathrm{~m}^{3} \mathrm{~s}^{-1}$ was selected as the threshold as shown in Fig. 15. Simulated runoff in the study area (Fig. 15) represents that rainfall translates into peak flow discharge with consideration for infiltration. The estimated peak discharges of surface water indicate the potential for runoff to entrain sediment once it encounters loose sediment. The results show that when debris flow occurs by surface runoff and entrains sediments in the study area, the 0.075 value is a reasonable large-scale estimate, and the debris flow hazardous region is easily noticeable.

As pointed out by Coe et al. (2008b), debris flows initiated by runoff are far less studied and poorly understood in comparison with landslide-induced debris flows, especially as a mechanism of erosion processes. Therefore, using the runoff module, this study aims to obtain quantitative insight on the hydrologic triggering of debris flow based on the simple model.

In order to obtain a qualitative comparison of the model presented, Flow-R (Horton et al., 2013) has been chosen as the reference method. Flow- $R$ is a distributed, semiempirical model for susceptibility assessments of debris flow 

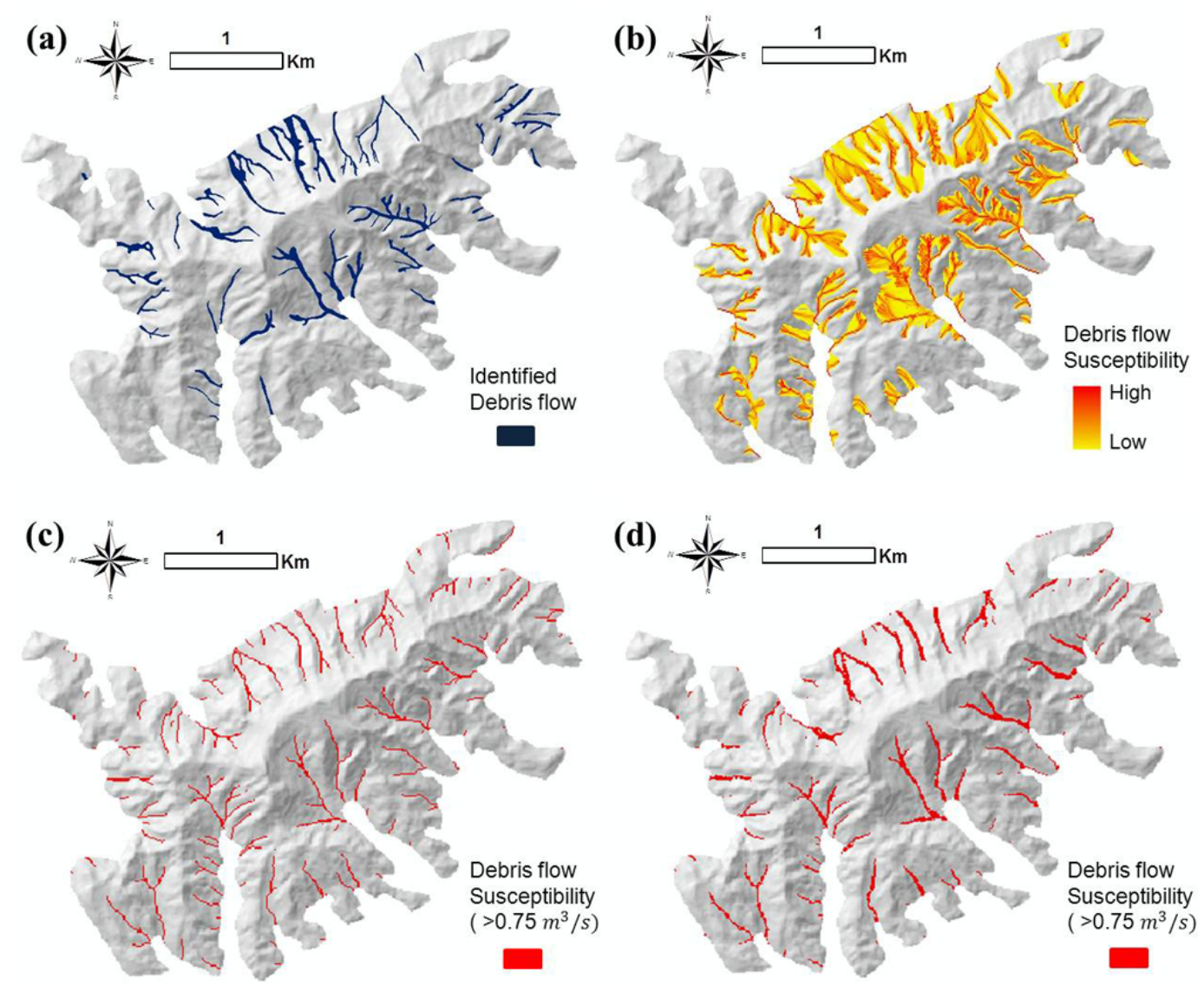

Fig. 15. Debris flow mapping and simulation results: (a) debris flow mapping in the study area, (b) Flow-R simulation result, (c) D-infinity method, and (d) multiple flow direction method.

developed at University of Lausanne. It assesses propagations using three critical factors of sediment availability, water input and gradient (Takahashi, 1981). The following calibrated parameters were used in the model: (1) flow accumulation and slope relationship - extreme event threshold, (2) Holmgren's exponent - 4, (3) slope angle algorithm of the energy loss function $-11^{\circ}$, and (4) velocity threshold $15 \mathrm{~m} \mathrm{~s}^{-1}$ (Horton et al., 2011).

Figure 15a depicts debris flow mapping developed by field investigation, aerial photograph and satellite imagery. Figure $15 \mathrm{~b}, \mathrm{c}$ and $\mathrm{d}$ show spatial distributions of debris flow susceptibility by different models: Flow-R, D-infinity method and multiple flow direction method, respectively. Figure $15 \mathrm{c}$ and $d$ indicate two interesting points about the results of the debris flow routing module.

First, comparing the results with the debris flow inventory map, good agreement can be found between the predicted debris flow paths and the inventory, despite the paucity of parameters for rheological properties and erosion rate. It was shown that the topography of the DEM is an important factor to determine debris flow propagation (Horton et al., 2011). In the framework of debris flow mapping, the predicted results have more routes than the observed debris flow routes shown in Fig. 15a. This is because the predicted results should be representative of the worst cases: flow in every potential route even where a landslide did not occur. To solve this problem, a coupled analysis with landslide and debris flow is needed. On the other hand, this module has the advantage by predicting susceptible zone for future extreme storms.

The second interesting issue arises from the comparison of two runoff schemes in the module as shown in Fig. 15c and $\mathrm{d}$. The runoff scheme in TRIGRS can calculate the amount of flow through each cell, and use various hydrological routing models. The results from the two model applications shown in Fig. 15 reveal the model outputs for the same topographic input, without any data related to sediment availability using geological and lithological information or land use. In Fig. 15, the width of the flow paths calculated by the multiple flow direction method is wider than that produced by the D-infinity method, due to the routing of flow to all the adjacent pixels of lower elevation. The module in TRIGRS allows the user to control the width using a weighting factor proportional to the slope raised to an exponent. However, in the scheme to predict debris flow susceptibility, it is not 
important to consider the flow width. Moreover, the module enables the improvement of the estimation by considering assessment of the propagation extent based on simple frictional laws and spreading algorithms.

\section{Conclusions}

This paper presented an approach to assess rainfall-induced shallow landslides and debris flows in a mountainous region in Seoul, South Korea. Model simulations resulted in reasonable estimates of the mountain hazards based on a deterministic approach.

One purpose of this paper was to suggest and verify an index $L_{\text {class }}$ (landslide ratio of each predicted FS class) for a pilot study. The biggest strength of this index is that it can estimate model performance quantitatively by minimizing the overestimated area, even in landslide-debris flow regions where the area of landslide scars is unknown or ambiguous. According to the results, the percentage of $\mathrm{LR}_{\text {class }}$ of unstable area is $70 \%$, and well reflects the effect of transient rainfall.

Another purpose was to introduce a GIS-based TRIGRS runoff module for predicting debris flow routes. By applying hydrological routing models, the results provide approximate information about debris flow routes. The operation of the runoff module was to delineate landslide-induced debris flow susceptibility zonation and to understand the processes for debris flows that are generated through runoff and erosion. This means that the model, originally developed for landslide assessment, has also been proved applicable for susceptibility analysis of debris flow in catchments with limited data availability. It is noteworthy that the proposed approach is useful when there are only a DEM and its derivative. Lastly, as demonstrated in this study, a combination of simulated runoff amount by heavy rain and surface water discharge thresholds can be useful in understanding and predicting debris flows generated by runoff and sediment entrainment.

In summary, though TRIGRS output is dependent on the resolution of DEM and precision of the geotechnical parameters used, this paper provides a practical approach for mapping the susceptibility to landslide and debris flow of each pixel in an area. This kind of approach has advantages in that (1) it considers "dynamic" (i.e. time-varying) analysis regarding the transient rainfall; (2) it provides workability with very fast computation; and (3) it gives useful results for preliminary assessments of hazards over large areas. Further research can be carried out to improve the TRIGRS model by coupling the landslide and debris flow runoff parameters.
Acknowledgements. This study was supported by the National Research Foundation of Korea under the Ministry of Education, Science, and Technology (under grant no. 2013M3A2A1054838) and Korean Ministry of Land, Transport and Maritime Affairs (MLTM) as part of the U-City Master and Doctor Course Grant Program.

Edited by: K.-T. Chang

Reviewed by: two anonymous referees

\section{References}

Baum, R. L., Savage, W. Z., and Godt, J. W.: TRIGRS - a FORTRAN program for transient rainfall infiltration and grid-based regional slope stability analysis, US Geological Survey OpenFile Report 2002-424, 38 pp., 2002.

Baum, R. L., Savage, W. Z., and Godt, J. W.: TRIGRS - A FORTRAN program for transient rainfall infiltration and grid-based regional slope stability analysis, version 2.0, US Geological Survey Open-File Report 2008-1159, 75 pp., 2008.

Berti, M. and Simoni, A.: Experimental evidences and numerical modelling of debris flow initiated by channel runoff, Landslides, 2, 171-182, 2005.

Berti, M., Genevois, R., Simoni, A., and Tecca, P. R.: Field observations of a debris flow event in the Dolomites, Geomorphology, 29, 265-274, 1999.

Birkinshaw, S. J., James, P., and Ewen, J.: Graphical User Interface for Rapid Set-up of SHETRAN Physically-Based River Catchment Model, Environ. Model. Softw., 25, 609-610, 2010.

Chen, C. Y., Chen, T. C., Yu, F. C., and Lin, S. C.: Analysis of time-varying rainfall infiltration induced landslide, Eng. Geol., 48, 466-479, 2005.

Chiang, S. H., Chang, K. T., Mondini, A. C., Tsai, B. W., and Chen, C. Y.: Simulation of event-based landslides and debris flows at watershed level, Geomorphology, 138, 306-618, 2012.

Chinnayakanahalli, K.: An objective method for the intercomparison of terrain stability models and incorporation of parameter uncertainty, Ms.D. thesis, Civil and Environmental Engineering, Utah State University, available at: http://www.neng.usu.edu/cee/ faculty/dtarb/Kiran_Thesis.pdf, 2004.

Coe, J. A., Cannon, S. H., and Santi, P. M.: Introduction to the special issue on debris flows initiated by runoff, erosion, and sediment entrainment in western North America, Geomorphology, 96, 247-249, 2008a.

Coe, J. A., Kinner, D. A., and Godt, J. W.: Initiation conditions for debris flows generated by runoff at Chalk Cliffs, central Colorado, Geomorphology, 96, 270-297, 2008b.

Crosta, G. B. and Frattini, P.: Distributed modelling of shallow landslides triggered by intense rainfall, Nat. Hazards Earth Syst. Sci., 3, 81-93, doi:10.5194/nhess-3-81-2003, 2003.

Dhakal, A. S. and Sidle, R.: Long-term modeling of landslides for different forest managent practices, Earth Surf. Proc. Land., 28 , 853-868, 2003.

Dietrich, W. E., Wilson, C. J., Montgomery, D. R., and McKean, J.: Analysis of erosion thresholds, channel networks and landscape morphology using a digital terrain model, J. Geol., 101, 259-178, 1993.

Dietrich, W. E., Reiss, R., Hsu, M. L., and Montgomery, D. R.: A Process-based model for colluvium soil depth and shallow lands- 
liding using digital elevation data, Hydrol. Process., 9, 383-400, 1995.

Ellen, S. D. and Fleming, R. W.: Mobilization of debris flows from soil slips, San Francisco Bay region, California, Geol. Soc. Am. Rev. Engng Geol., 7, 31-40, 1987.

Ewen, J., Parkin, G., and O'Connell, P. E.: SHETRAN: distributed river basin flow and transport modeling system, J. Hydrol. Eng., 5, 250-258, 2000.

Godt, J. W., Baum, R. B., Savage, W. Z., Salciarini, D., Schulz, W. H., and Harp, E. L.: Transient deterministic shallow landslide modeling: Requirements for susceptibility and hazard assessments in a GIS framework, Eng. Geol., 102, 214-226, 2008.

Gomes, R. A. T., Guimaraes, R. F., Carvalho Júnior, O. A., Fernandes, N. F., and Amaral Jr., E. V.: Combining spatial models for shallow landslides and debris flows prediction, Remote Sens., 5, 2219-2237, 2013.

Gregoretti, C.: The initiation of debris flow at high slopes: experimental results, J. Hydrol. Res., 38, 83-88, 2000.

Hammond, C. J., Prellwitz, R. W., and Miller, S. M.: Landslide hazard assessment using Monte Carlo Simulation. Proceedings 6th International symposium on Landslides, Christchurch, New Zealand, Balkema publisher, 959-964, 1992.

Horton, P., Jaboyedoff, M., Zimmermann, M., Mazotti, B., and Longchamp, C.: Flow-R, a model for susceptibility mapping at a regional scale - some case studies, IJEGE.2011-03.B-095, 2011.

Horton, P., Jaboyedoff, M., Rudaz, B., and Zimmermann, M.: Flow$\mathrm{R}$, a model for susceptibility mapping of debris flows and other gravitational hazards at a regional scale, Nat. Hazards Earth Syst. Sci., 13, 869-885, doi:10.5194/nhess-13-869-2013, 2013.

Huang, J. C. and Kao, S. J.: Optimal estimator for assessing landslide model performance, Hydrol. Earth Syst. Sci., 10, 957-965, doi:10.5194/hess-10-957-2006, 2006.

Iverson, R. M.: Landslide triggering by rain infiltration, Water Resour. Res., 36, 1897-1910, 2000.

Iverson, R. M., Reid, M. E., and LaHusen, R. G.: Debris-flow mobilization from landslides, Ann. Rev. Earth Planet. Sci., 25, 85138, 1997.

Iverson, R. M., Reid, M. E., Iverson, N. R., LaHusen, R. G., Logan, M., Mann, J. E., Brien, D. L.: Acute sensitivity of landslide rates to initial soil porosity, Science, 290, 513-516, 2000.

Jelínek, R. and Wagner, P.: Landslide hazard zonation by deterministic analysis (Veká Čausa landslide area, Slovakia), Landslides, 4, 339-350, 2007.

Johnson, A. M. and Rodine, J. D.: Debris flow, in: slope Instability, John Wiley, New York, 257-361, 1984.

Kim, D., Im, S., Lee, S. H., Hong, Y., and Cha, K. S.: Predicting the Rainfall-Triggered Landslides in a Forested Mountain Region Using TRIGRS Model, J. Mt. Sci., 7, 83-91, 2010.

Korean Geotechnical Society: Research contract report: addition and complement causes survey of Mt. Woomyeon landslide, 2011.

Korean Society of Civil Engineers: Research contract report: causes survey and restoration work of Mt. Woomyeon landslide, 2012.

Larsen, I. J., Pederson, J. L., and Schmidt, J. C.: Geologic versus wildfire controls on hillslope and debris flow initiation in the Green River canyons of Dinosaur National Monument, Geomorphology, 81, 114-127, 2006.

Liao, Z., Hong, Y., Kirschbaum, D., Adler, R. F., Gourley, J. J., and Wooten, R.: Evaluation of TRIGRS (transient rainfall infiltration and grid-based regional slope-stability analysis)'s predictive skill for hurricane-triggered landslides: a case study in Macon County, North Carolina, Nat. Hazards, 58, 325-339, 2011.

Liu, C. N. and Wu, C. C.: Mapping susceptibility of rainfalltriggered shallow landslides using a probabilistic approach, Environ. Geol., 55, 907-915, 2008.

Montgomery, D. R. and Dietrich, W. E.: A physically based model for the topographic control on shallow landsliding, Water Resour. Res., 30, 1153-1171, 1994.

Montgomery, D. R., Sullivan, K., and Greenberg, H. M.: Regional test of a model for shallow landsliding, Hydrol. Process., 12, 943-955, 1998.

Montrasio, L., Valentino, R., and Losi, G. L.: Towards a real-time susceptibility assessment of rainfall-induced shallow landslides on a regional scale, Nat. Hazards Earth Syst. Sci., 11, 1927-1947, doi:10.5194/nhess-11-1927-2011, 2011.

Morrissey, M. M., Wieczorek, G. F., and Morgan, B. A.: A comparative analysis of hazard models for predicting debris flows in Madison County, Virginia, USGS, 2001.

National Geographic Information Institute: Official archive for restoration work of Mt. Woomyeon landslide, 2011.

O'Callaghan, J. F. and Mark, D. M.: The Extraction of Drainage Networks From Digital Elevation Data, Computer Vision, Graphics Image Process., 28, 328-344, 1984.

Pack, R. T., Tarboton, D. G., and Goodwin, C. N.: Terrain stability mapping with SINMAP, Technical description and users guide for version 1.00, Report and software available at: http://www. engineering.usu.edu/dtarb/ (last access: 15 June 2007), 1998.

Pack, R. T., Tarboton, D. G., and Goodwin, C. N.: Assessing terrain stability in a GIS using SINMAP, in: 15 th annual GIS conference, GIS 2001, Vancouver, 56-68, 19-22 February 2001.

Quinn, P., Beven, K., Chevallier, P., and Planchon, O.: The Prediction of Hillslope Flow Paths for Distributed Hydrological Modeling Using Digital Terrain Models, Hydrol. Process., 5, 59-80, 1991.

Raia, S., Alvioli, M., Rossi, M., Baum, R. L., Godt, J. W., and Guzzetti, F.: Improving predictive power of physically based rainfall-induced shallow landslide models: a probabilistic approach, Geosci. Model Dev. Discuss., 6, 1367-1426, doi:10.5194/gmdd-6-1367-2013, 2013.

Salciarini, D., Godt, J. W., Savage, W. Z., Conversini, P., Baum, R. L., and Michael, J. A.: Modeling regional initiation of rainfallinduced shallow landslides in the eastern Umbria Region of central Italy, Landslides, 3, 181-194, 2006.

Salciarini, D., Godt, J. W., Savage, W. Z., Baum, R. L., and Conversini, P.: Modeling landslide recurrence in Seattle, Washington, USA, Eng. Geol., 102, 227-237, 2008.

Shaw, S. and Johnson, D.: Slope Morphology Model Derived from Digital Elevation Data, in: Proceedings, NW Arc/Info Users Conference. Coeur d'Alene, ID, 23-25 October 1995. 12 pp, The Klamath Resource Information System (KRIS), available at: http://www.krisweb.com/biblio/biblio.htm, 1995.

Sorbino, G., Sica, C., and Cascini, L.: Susceptibility analysis of shallow landslides source areas using physically based models, Nat. Hazards, 53, 313-332, 2010.

Takahashi, T.: Debris Flow, IAHR Monograph Balkema, Rotterdam, 1991. 
Takahashi, T.: Estimation of potential debris flows and their hazardous zones; soft countermeasures for a disaster, J. Natural Disaster Sci., 3, 57-89, 1981.

Tarboton, D. G.: A new method for the determination of flow directions and contributing areas in grid digital elevation models, Water Resources Research v.33, 2, 309-319, 1997.

Tognacca, C., Bezzola, G. R., and Minor, H. E.: Threshold criterion for debris-flow initiation due to channel-bed failure, in: DebrisFlow Hazards Mitigation: Mechanics, Prediction, and Assessment, edited by: Wieczorek, G. F. and Naeser, N. D., Balkema, Rotterdam, The Netherlands, 89-97, 2000.
Vieira, B. C., Fernandes, N. F., and Filho, O. A.: Shallow landslide prediction in the Serra do Mar, São Paulo, Brazil, Nat. Hazards Earth Syst. Sci., 10, 1829-1837, doi:10.5194/nhess-101829-2010, 2010.

Wang, C., Marui, H, Furuya, G., Watanabe, N.: Two integrated models simulating dynamic process of landslide using GIS, Landslide Sci. Practice, 3, 389-395, 2013.

Wu, W. and Sidle, R. C.: A distributed slope stability model for steep forested basins, Water Resour. Res., 31, 2097-2110, 1995. 